\title{
List of Genealogies
}

Genealogy A: Arnulfings, Pippinds, Carolingians

xxxii

Genealogy B: The descendants of Pippin and Alpaida xxxiii

Genealogy C: The family of Charles

xxxiv-Xxxv 


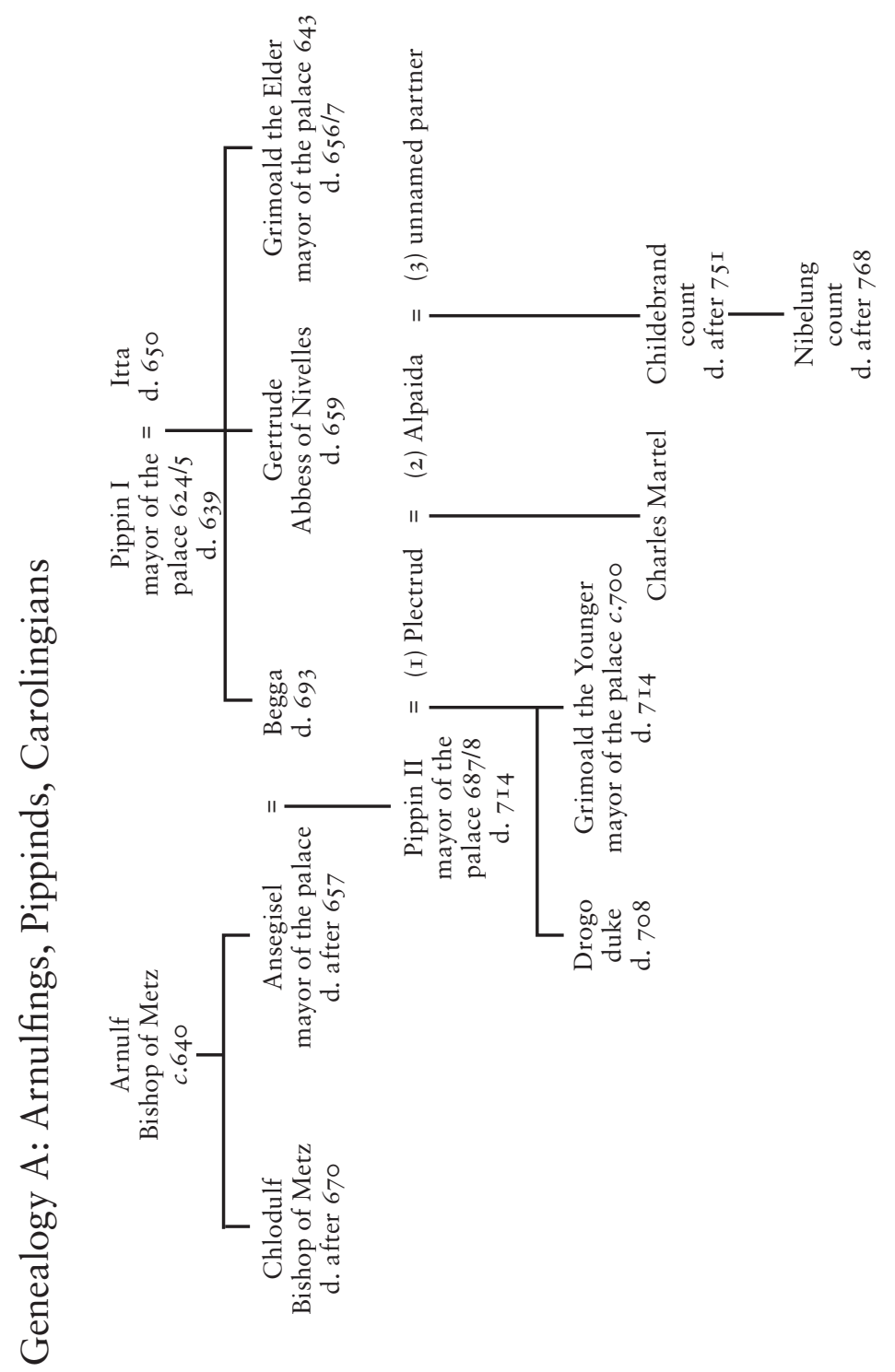




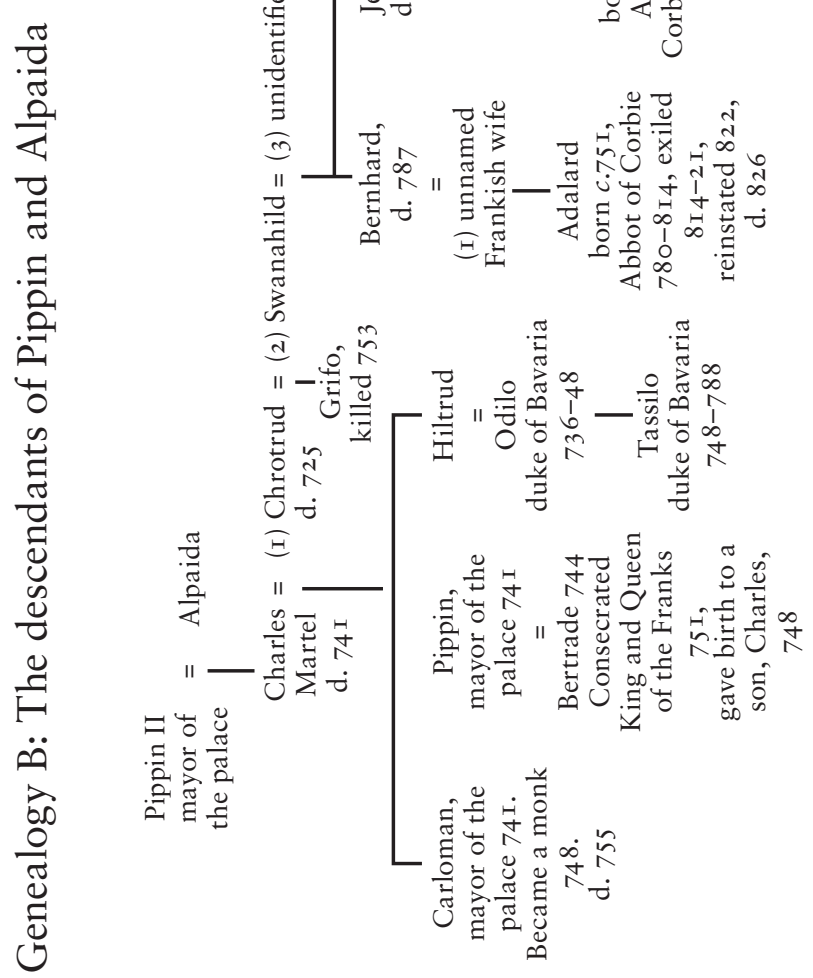




\section{Genealogy C: The family of Charles}

Charles, born 748 , King 768

$$
\begin{aligned}
& =\text { Himiltrud 768, }=\text { Unknown }= \\
& \text { Frankish } \\
& \text { Noblewoman }
\end{aligned}
$$

\section{wife (married in 770 )}$$
1
$$

Pippin,

born 769 .

Exiled to monas-

tery of Prüm 792.

d. 8II.

1

Hildegard, married in $77 \mathrm{I}$. Born 758 daughter of Imma (daughter of duke of Alamans) and Count Gerold.

d. 783 . partner$$
\mid
$$

Theodrada

Hruodhaid, born 784 ,

d. after 800 unknown $=$ born 785 . Before

8I 4 became Abbess of Argenteuil,

d. after 844 .
Fastrada 783 , d. 794, daughter of East Frankish Count Radulf

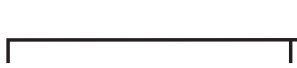

Charles 'the Younger', b. $772 / 3$. King of the

Franks 800 . d. 8II.
Adalheid

born 773 .

d. 774 .
Rotrud, born $c .775$, d. 8 IO.

Betrothed to

Constantine VI 78I, betrothal broken off 787 .

Gave birth $c .800$ by partner unknown Louis born $c .800$.

840 abbot of St.

Denis and archchancellor. d. 867
Bernard born $c .797$ Carloman born 777 . Renamed Pippin and made King of Italy, 78I. $=$ unnamed wife 795 . d. 8Io.
Hildrud, born $c .878$ d. after 800

\section{man
777.
Pippin and
of Italy, 78
wife 795}

Adalheid, born $c .798$ $8 \mathrm{I}_{2} / 8 \mathrm{I}_{3}$ King of Italy.

$$
\text { d. } 8 \mathrm{I} 8 \text {. }
$$

Pippin, count, d. after 840 . 


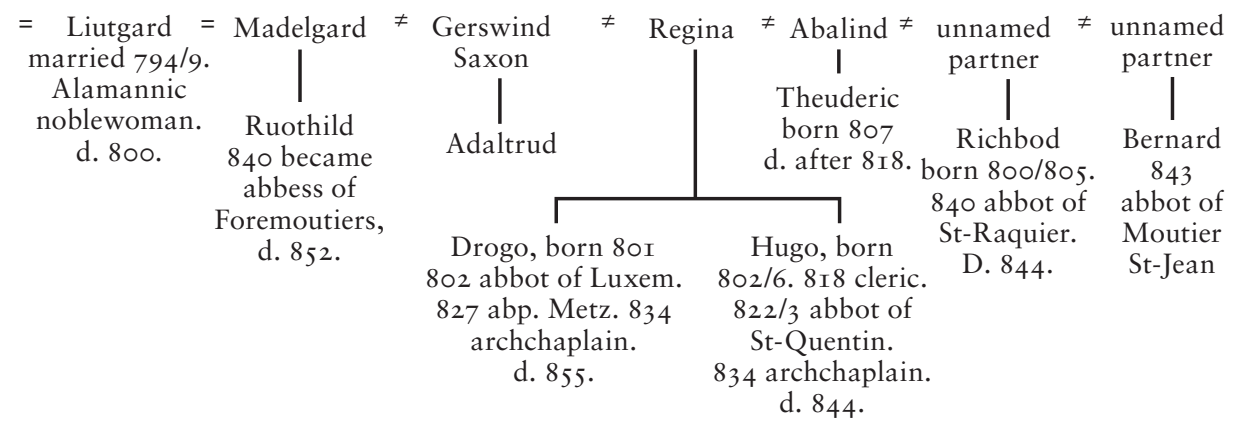

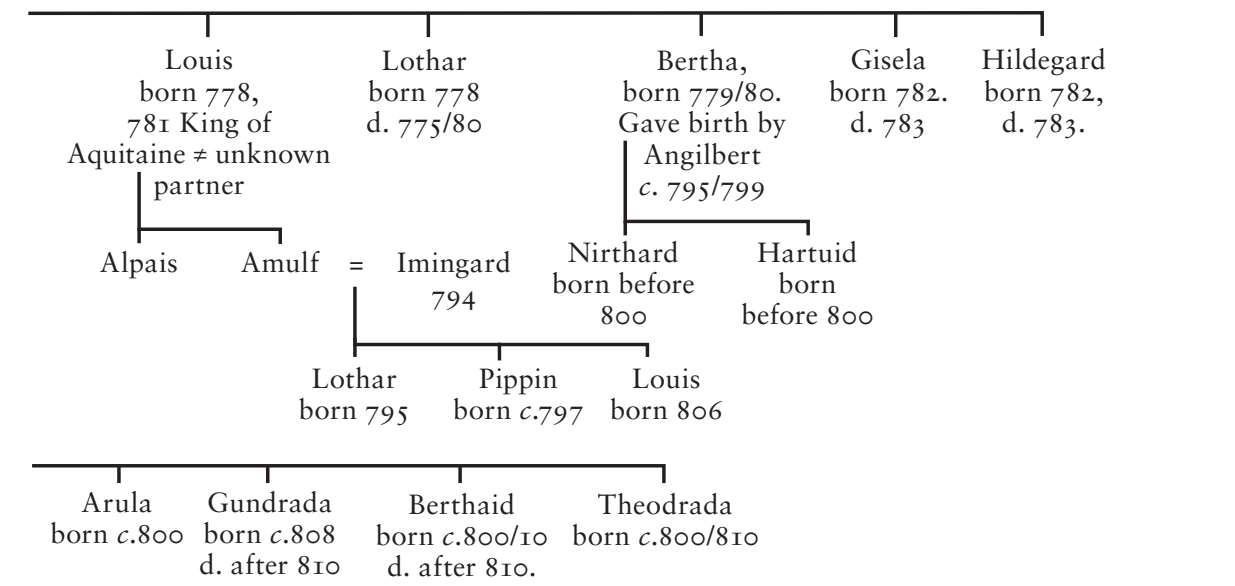




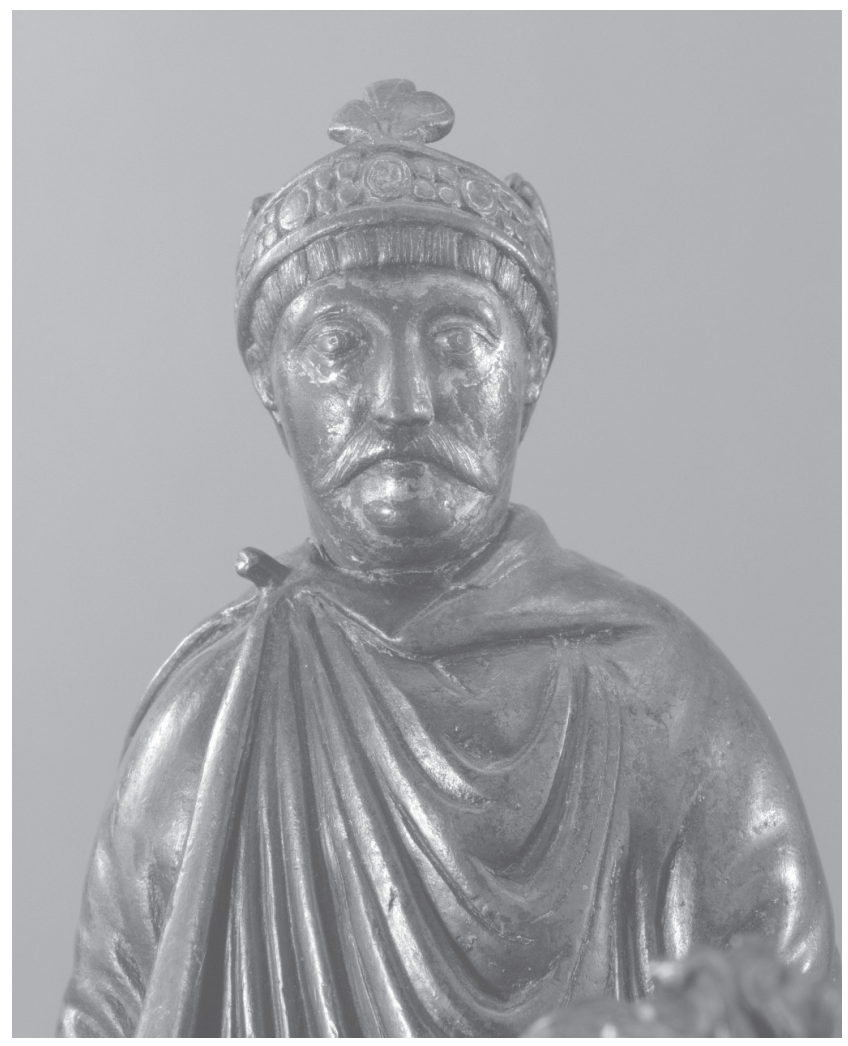

Bronze equestrian statuette of Charles. 